\title{
Revisão dos gêneros Chariergus White, Rierguscha Viana e descrição de Allopeba gen.n. (Coleoptera, Cerambycidae, Compsocerini) ${ }^{1}$
}

\author{
Dilma Solange Napp ${ }^{2}$ \\ Dalton T. Reynaud ${ }^{3}$
}

\begin{abstract}
Revision of the genera Chariergus White, Rierguscha Viana and description of Allopeba gen.n. (Coleoptera, Cerambycidae). Chariergus White, 1855 is interpreted based on C. tabidus (Klug, 1825) (type species designated by Thomson, 1864). Allopeba gen.n. is proposed for A. paranaensis (Napp \& Reynaud, 1998) comb.n. (type species), A. signaticornis (Lucas, 1857) comb.n. and $A$. quadripunctata (Lucas, 1857) comb.n. Rierguscha Viana, 1970 and its species are redescribed. The morphology of Chariergus tabidus (Klug, 1825) and Allopeba signaticornis (Lucas, 1857), including the mouth pieces, endosternites, wing venation and male and female terminalia, is presented. Key for the genera and species is added.

KEY WORDS. Allopeba, Chariergus, Rierguscha, new genus, revision
\end{abstract}

O estudo das espécies atualmente incluídas em Chariergus White, 1855 revelou que as mesmas não são congenéricas. Chariergus tabidus (Klug, 1825) apresenta vários caracteres estruturais distintos de C. paranaensis Napp \& Reynaud, 1998, C. quadripunctata Lucas, 1857 e C. signaticornis Lucas, 1857 o que justifica a proposição de um novo gênero para estas espécies.

Pela revisão da literatura constatou-se que a designação da espécie-tipo de Chariergus feita por MONNÉ (1993) foi um equívoco, considerando que THOMSON (1864) já havia designado Cerambyx tabidus Klug, 1825 como espécie-tipo, o que altera substancialmante o conceito do gênero.

Neste trabalho apenas Chariergus caeruleus Napp \& Reynaud, 1998 é considerada congenérica com C. tabidus (Klug, 1825) e Allopeba gen.n. é proposto para abrigar as demais espécies. Como o novo gênero é semelhante a Rierguscha Viana, 1970, considerou-se conveniente incluí-lo nesta contribuição. Chariergus, Rierguscha e as espécies conhecidas dos três gêneros são redescritos. Apresenta-se a morfologia de Chariergus tabidus e Allopeba signaticornis. Chaves para identificação dos gêneros e espécies são acrescentadas.

Técnicas de dissecção e a terminologia utilizadas seguem NAPP (1994) e MARQUES \& NAPP (1996).

1) Contribuição número 1061 do Departamento de Zoologia, Universidade Federal do Paraná.

2) Departamento de Zoologia, Universidade Federal do Paraná. Caixa Postal 19020, 81531-990 Curitiba, Paraná, Brasil. Pesquisador do CNPq.

3) Bolsista do CNPq. 
Considerando a recente publicação do catálogo de MonNÉ (1993), as citações sob cada táxon restringem-se às da descrição original e à de MONNÉ (1993). Quando apropriado, todas as citações referentes a um táxon são mencionadas.

As siglas citadas no texto correspondem às seguintes instituições: BMNH The Natural History Museum, Londres; DZUP - Departamento de Zoologia, Universidade Federal do Paraná, Curitiba; IMLT - Instituto Miguel Lillo, Tucumán; MACN - Museo Argentino de Ciências Naturales "Bernardino Rivadavia", Buenos Aires; MCNZ - Museu de Ciências Naturais, Fundação Zoobotânica do Rio Grande do Sul, Porto Alegre; MNHN-Muséum National d'Histoire Naturelle, Paris; MNRJ - Museu Nacional, Universidade Federal do Rio de Janeiro, Rio de Janeiro; MZSP - Museu de Zoologia, Universidade de São Paulo, São Paulo.

\section{Chave para gêneros e espécies}

1. Pernas (Fig. 98) delgadas, muito longas; fêmures sublineares, os posteriores ultrapassam o ápice elitral nos dois sexos, nos machos em, pelo menos, um terço de seu comprimento. Protórax (Figs 11,98) subtuberculado a inerme aos lados, gradualmente alargado para trás, a maior largura após o meio. Lobos oculares inferiores bem desenvolvidos, salientes, ocupam quase toda a região lateral da cabeça. Cabeça projetada em rostro curto (Fig. 3). Processo prosternal (Fig. 12) não afilado entre as procoxas ..... Chariergus . . . . 2

-. Pernas (Figs 99-101) pouco alongadas, robustas; fêmures clavados; os posteriores ultrapassam o ápice elitral pela região apical dos fêmures nos machos, nas fêmeas não alcançam o ápice elitral. Protórax (Figs 55, 89, 99, 100) tuberculado aos lados, a maior largura ao nível do meio. Lobos oculares inferiores pouco desenvolvidos. Cabeça não rostrada (Figs 46, 85). Processo prosternal (Figs 58,90 ) afilado entre as procoxas .................... 3

2(1). Élitros azul-metálicos. Urosternitos com pubescência esbranquiçada curta, esparsa. Élitros com pontos subcontíguos a corrugados até os ápices. Metafêmures, nos machos, ultrapassam o ápice elitral por quase metade de seu comprimento. Protórax inerme aos lados. Brasil (Bahia, Minas Gerais, Espírito Santo). (Fig. 98) ...................... caeruleus

-. Élitros amarelos. Urosternitos com pubescência esbranquiçada alongada, densa. Pontos elitrais não contíguos ou corrugados, mais finos e superficiais no terço apical. Metafêmures, nos machos, ultrapassam o ápice elitral em um terço de seu comprimento. Protórax subtuberculado aos lados. BRASIL (Goiás, Minas Gerais, Espírito Santo ao Rio Grande do Sul), URUGUAI ... . C. tabidus

3(1). Fêmures (Figs 92, 93, 99) com clava abrupta. Metatarsômeros curtos, o primeiro algo intumescido (Figs 96,97). Escapo robusto, com comprimento subigual à metade do III (Fig. 88). Fronte curta; distância entre o alvéolo antenal e a inserção da mandíbula menor que o diâmetro do alvéolo (Figs $85,86)$. Genas aguçadas, em vista frontal, divergentes. Artículos apicais dos palpos maxilares (Fig. 87) e labiais cilíndricos, truncados no ápice. Processo prosternal (Fig. 90) reduzido, laminar, o ápice atinge a metade do comprimento de uma coxa anterior. Processo mesosternal (Fig. 91) com ápice rombo ............................ Rierguscha ....4 4 
-. Fêmures (Figs 68, 70, 100, 101) gradualmente clavados. Metatarsômeros longos, o primeiro não intumescido (Figs 72, 74). Escapo cilíndrico, com dois terços do comprimento do III (Fig. 54). Fronte transversa; distância entre alvéolo antenal e a inserção da mandíbula 1,3 vezes o diâmetro do alvéolo (Figs 46, 47). Genas arredondadas, em vista frontal paralelas. Artículos apicais dos palpos maxilares e labiais (Figs 51,53) pouco alongados, estreitados na base e um pouco dilatados para os ápices. Processo prosternal (Fig. 58) não laminar, o ápice atinge a margem posterior das procoxas. Processo mesosternal (Fig. 61) aguçado no ápice .................. Allopeba ....5

4(3). Antenas e pernas unicolores, pretas a castanhas. Cabeça, protórax e face ventral castanhos; élitros verde-escuros, opacos. Pronoto densamente microcorrugado, revestido por densa pubescência esbranquiçada. Élitros com denso revestimento de pubescência esbranquiçada, quase oblitera o tegumento. ARGENTINA (Tucumán, Catamarca) ............... viridipennis

-. Antenas negras, o escapo vermelho, os artículos IX-XI branco-amarelados. Pernas bicolores: negras com as clavas dos fêmures vermelhas. Cabeça, protórax e esternos torácicos vermelhos ou vermelho-acastanhados; élitros verdes, brilhantes. Pronoto e élitros com pontuação e pubescência esparsas. Bolívia (Santa Cruz), Argentina (Salta). (Fig. 99).......... R. bicolor

5(3).Élitros unicolores, alaranjados; escutelo concolor com os élitros. Meso- e metasterno com densa pubescência branco-sedosa, alongada. (Pernas e antenas negras, artículos antenais IX-X branco-amarelados; élitros, cabeça e protórax concolores, finamente pontuados e pubescentes). BRASIL (Goiás, Minas Gerais ao Rio Grande do Sul) ............... signaticornis

-. Cada élitro com duas faixas ou manchas negras, uma antemediana e outra após o meio. Escutelo preto a castanho. Meso- e metasterno com pubescência esparsa .............................. 6

6(5). Pronoto e élitros fina e densamente pontuados e pubescentes, opacos. Protórax gradualmente expandido após a constrição anterior, esta moderadamente acentuada. BRASIL (Minas Gerais ao Rio Grande do Sul). (Fig. 100) ...... ................................... quadripunctata

-. Pronoto liso, brilhante; élitros com pontuação e pubescência esparsas, aspecto brilhante. Protórax fortemente expandido após a constrição anterior, esta bem acentuada. Brasil (Paraná, Santa Catarina, Rio Grande do Sul). (Fig.

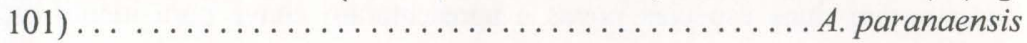

\section{Chariergus White, 1855}

Chariergus White, 1855: 216. - Lucas, 1857: 188. - Thomson, 1860: 369. - Thomson, 1864: 263, 460. - Lacordaire, 1869: 39. - Gounelle, 1911: 183, 252. - Aurivillius, 1912: 334. - Blackwelder, 1946: 579. - Monné, 1993: 28 (cat.). - Monné \& Giesbert, 1994: 103 (checklist). - Napp \& Reynaud, 1998: 155.

Espécie-tipo: Cerambyx tabidus Klug, 1825, por designação de Thomson, 1864: 263.

Chariergus foi proposto por WHITE (1855) para duas espécies, Cerambyx tabidus e C. phtisicus, ambas de KLUG (1825). WHITE (1855) não caracterizou o 
gênero e, com relação a C. tabidus, limitou-se a transcrever as duas primeiras linhas da descrição de KLUG (1825), não fazendo menção ao colorido das antenas que, na espécie de KLUG (1825), são inteiramente castanhas. Cerambyx phtisicus foi posteriormente alocada por BATES (1867) em Pandrosus Bates, 1867.

LUCAS (1857) acrescentou ao gênero Chariergus signaticornis e C. quadripunctatus, ambas do Brasil. LUCAS (1857) argumentou que a espécie tratada por WHITE (1855) como Cerambyx tabidus Klug, 1825 correspondia a Oregostoma signaticornis (Dejean, 1837 nomen nudum); ao figurar exemplar sob esta denominação, LUCAS (1857) validou a espécie, tornando-se o autor da mesma.

THOMSON (1860) foi o primeiro a apresentar uma caracterização do gênero. Os caracteres mencionados por este autor correspondem integralmente à Chariergus tabidus (Klug, 1825), única espécie tratada e designada, posteriormente, como espécie-tipo do gênero (THOMSON 1864).

LACORDAIRE (1869) redescreveu Chariergus, dando a autoria do gênero a THOMSON (1860), no que foi seguido por autores subseqüentes (GOUNELLE 1911; AURIVILLIUS 1912; BLACKWELDER 1946). LACORDAIRE (1869) citou para o gênero apenas Cerambyx tabidus Klug e Chariergus quadripunctatus Lucas, não fazendo menção a Chariergus signaticornis Lucas.

GOUNELLE (1911) seguiu LUCAS (1857), aceitando como equivocada a identificação de WHITE (1855). AURIVILLIUS (1912) arrolou, com dúvidas, Chariergus tabidus White na sinonímia de $C$. signaticornis Lucas.

MONNÉ (1993) reconheceu WHITE (1855) como autor do gênero, mas, aparentemente, não observou a designação da espécie-tipo feita por THOMSON (1864) nem a inclusão de duas espécies válidas quando o gênero foi proposto. Seguindo a interpretação de LUCAS (1857) e GoUNELLE (1911) para a espécie tratada por WHITE (1855), MONNÉ (1993) indicou como espécie-tipo do gênero, por monotipia, "Chariergus tabidus White, 1855 (= Chariergus signaticornis Lucas, 1857, non Cerambyx tabidus Klug, 1825)".

Pelo exposto, independente de qual tenha sido o material estudado por WHITE (1855) - questão que só poderá ser elucidada se examinado o material deste autor - a espécie-tipo de Chariergus é Cerambyx tabidus Klug, 1825, por designação de THOMSON (1864), e o gênero deve ser interpretado com base nesta espécie.

A mais recente contribuição ao gênero foi de NAPP \& REYNAUD (1998) que descreveram duas espécies novas e apresentaram chave para identificação das espécies.

Cabeça (Fig. 3) projetada em rostro curto à frente dos olhos. Distância entre o alvéolo antenal e a inserção da mandíbula subigual ao dobro do diâmetro do alvéolo. Fronte (Fig. 4) tão larga quanto longa, aplanada, declive, ligeiramente deprimida entre os tubérculos anteníferos. Clípeo quadrangular, quase tão longo quanto metade do comprimento da fronte. Tubérculos anteníferos não projetados, arredondados. Submento (Fig. 2) com projeção curta e transversa entre a inserção das maxilas. Olhos finamente facetados, chanfrados; lobos inferiores bem desenvolvidos, salientes, cerca de três vezes tão largos quanto os superiores, ocupam quase toda a região lateral da cabeça; ligação entre os lobos com cinco fileiras de 
omatídios, pouco mais estreita que um lobo superior; superiores com 7-8 fileiras de omatídios, mais aproximados entre si que a distância entre os tubérculos anteníferos. Área malar, no maior comprimento, subigual à metade do diâmetro do lobo ocular inferior; no menor comprimento, com um terço. Mandíbulas (Fig. 5) delgadas, de secção triangular, não angulosas no terço apical, aguçadas no ápice. Artículos apicais dos palpos maxilares e labiais os mais longos, triangulares (Figs 8, 10).

Antenas com onze artículos, filiformes, desarmadas, sem sulcos ou carenas, mais longas que o corpo nos dois sexos; nos machos ultrapassam o ápice elitral em 3,5-4,0 artículos. Escapo cilíndrico, sem sulcos ou depressões, tão longo quanto metade do comprimento do III. Artículos III-XI cilíndricos, delgados; o III cerca de um terço mais longo que o IV, este pouco mais curto que o V; VI-IX subiguais e decrescentes; XI aproximadamente um terço mais curto que o III, não apendiculado.

Protórax (Fig. 11) mais longo que largo, sensivelmente mais atenuado para a margem anterior onde é fracamente constrito. Lados subinermes a inermes, gradualmente alargados para trás, a maior largura após o meio. Pronoto um pouco convexo, sem gibosidades. Prosterno, nos machos, sem pontuação sexual. Processo prosternal triangular, não afilado entre as procoxas, o ápice projetado (Figs 12, 13). Cavidades cotilóides anteriores fortemente angulosas aos lados, abertas atrás. Mesosterno e mesepisternos intumescidos (Figs 15, 16). Processo mesosternal triangular (Fig. 15), pouco mais largo que o prosternal, o ápice rombo. Cavidades cotilóides médias abertas aos lados. Metasterno pouco mais curto que o pró- e mesosterno somados. Metepisternos sinuosamente estreitados para trás.

Élitros (Fig. 98) estreitos e alongados, na base pouco mais largos que o protórax; úmeros arredondados; lados paralelos até quase os ápices; estes truncados, ligeiramente oblíquos para a sutura; cada élitro com duas carenas dorsais pouco manifestas.

Pernas longas e delgadas, as posteriores mais longas que o dobro do comprimento das anteriores. Fêmures (Figs 27, 29, 98) subcilíndricos, pouco e gradualmente engrossados para os ápices, sem sulcos ou carenas; abas apicais arredondadas; os posteriores ultrapassam o ápice elitral por $1 / 3-1 / 2$ de seu comprimento. Tíbias cilíndricas e delgadas, não carenadas. Esporões tibiais curtos. Tarsos (Figs 31, 32) alongados, com comprimentos crescentes; metatarsômero I cerca de um terço mais longo que os II-III somados, o II um terço mais longo que o III; este com lobos estreitos. Escovas tarsais sem faixa glabra.

Abdômen (Fig. 26) com urosternito VI parcialmente visível; urosternito V transverso, emarginado no bordo apical.

Fêmea. Forma similar à do macho. Antenas ultrapassam o ápice elitral em 2,5 - 3,0 artículos; artículo XI com metade do comprimento do III. Fêmures posteriores ultrapassam ápice elitral em 1/5 de seu comprimento. Abdômen (Fig. 25) com cinco urosternitos visíveis. Sétimo tergito com escova apical de longos pêlos avermelhados, sedosos, curvados para baixo e para frente (Fig. 33); ligado ao oitavo tergito por uma membrana semicircular recoberta de microcerdas.

Discussão. Chariergus diferencia-se prontamente de Allopeba por: 1) cabeça projetada em rostro curto e constrita na região posterior; 2) lobos oculares inferiores 
bem desenvolvidos e salientes, ocupam quase toda a região lateral da cabeça; 3 ) protórax gradualmente alargado para trás, no máximo subtuberculado aos lados; 4) artículos apicais dos palpos maxilares e labiais fortemente triangulares; 5) pernas longas e delgadas; fêmures sublineares, nos machos ultrapassam o ápice elitral em, pelo menos, um terço de seu comprimento; metatarsômero I conspicuamente mais longo que II + III, o II cerca de um terço mais longo que o III; 6) processo prosternal triangular, não afilado entre as procoxas; 7) mesosterno e mesepisternos intumescidos. Em Allopeba a cabeça é curta à frente dos olhos e não constrita na região posterior; os lobos oculares inferiores são moderadamente desenvolvidos, pouco salientes; o protórax é tuberculado aos lados; os artículos apicais dos palpos maxilares e labiais são pouco dilatados para os ápices; as pernas são pouco alongadas, com fêmures clavados, os posteriores ultrapassam pouco o ápice elitral; os metatarsômeros são moderadamente alongados, o processo prosternal é afilado entre as procoxas e o mesosterno e mesepisternos não são intumescidos. Além disso, a venação alar e o metendosternito de Chariergus tabidus (Figs 17, 20-23) apresentam caracteres distintos dos de A. signaticornis (Figs 63-65, 77).

No aspecto geral, Chariergus apresenta algumas semelhanças com Mimochariergus Zajciw, 1960. Neste gênero, entretanto, os processos intercoxais são largos, o mesosternal mais largo que uma coxa média; a cabeça não é projetada à frente dos olhos; os fêmures são clavados, os posteriores pouco alongados; e as fêmeas não apresentam escova pigidial.

\section{Chariergus tabidus (Klug, 1825)}

Figs 1-43

Cerambyx tabidus Klug, 1825: 461, pl. 43, fig. 4.

Chariergus tabidus; White, 1855: 216. - Thomson, 1860: 369. - Thomson, 1864: 263. - Lacordaire, 1869: 40. - Gounelle, 1911: 183. - Monné, 1993: 28 (cat.). - Monné \& Giesbert, 1994: 103. Napp \& Reynaud, 1998: 157.

Macho. Cabeça, protórax, mesosterno e coxas alaranjadas, as metacoxas até acastanhadas. Antenas, pernas, metasterno e urosternitos castanhos a castanho-avermelhados. Élitros amarelados. Escutelo amarelo-alaranjado.

Cabeça fina e densamente pontuada com pubescência amarelada bem aparente; genas quase lisas; gradualmente elevada na região posterior e fortemente constrita após os lobos oculares (Figs 2, 3); suturas gulares (Fig. 2) curtas e convergentes. Mandíbulas (Figs 5-7): ápice aguçado e projetado; bordo cortante sem dentes; com franja de pêlos curtos ao longo do bordo interno. Maxilas (Fig. 10): cardo desenvolvido; estipe transverso, dividido em disti- e basistipe. Gálea cilíndrico-capitada, alcança o meio do terceiro artículo do palpo; região apical densamente pilosa, os pêlos um pouco capitados; com anel esclerotinizado na base, esta retrátil entre o palpífero e a lacínea. Artículo apical do palpo tão longo quanto os dois anteriores somados, de aspecto triangular; segundo artículo pouco mais longo que o terceiro. Lábio (Fig. 8): mento trapezóide. Lígula membranosa, na face externa com área mais pigmentada com alguns pêlos alongados; bordo apical com chanfro estreito, arredondado, os lobos laterais desenvolvidos alcançam a base do 
artículo apical do palpo; face interna (Fig. 9) com duas estreitas faixas laterais de pilosidade. Artículo apical do palpo o mais longo, conspicuamente triangular; palpíferos individualizados.

14

15

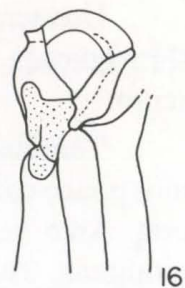

Figs 1-16. Chariergus tabidus. (1-4) Cabeça, vistas dorsal, ventral, lateral e anterior; (5-7) mandibula, vistas dorsal, lateral e ventral; (8) lábio; (9) lígula, face interna; (10) maxila; (11-13) protórax, vistas dorsal, ventral e lateral; (14) proendosternito; (15) mesosterno; (16) idem, lateral. (flp) Franja lateral de pêlos, (pro) proendosternito, (sg) suturas gulares, (t) tendão. Figs $1-3,5-10,12-16$, respectivamente, na mesma escala. Barra $=1 \mathrm{~mm}$. 
Antenas ultrapassam ápice elitral em 3,5-4,0 artículos. Escapo com pontuação fina, adensada, com pubescência castanho-amarelada moderadamente densa; artículos III-XI muito fina e densamente pontuados, com cerdas castanhas pouco densas na face inferior dos III-V, a pubescência adensada para os artículos distais.

Pronoto muito fina, rasa e densamente pontuado-corrugado; pubescência alaranjada, densa, transversalmente deitada. Lados do protórax microcorrugados com pubescência esparsa. Prosterno brilhante, subglabro, fina e superficialmente estriado; processo prosternal e região anterior às cavidades coxais microcorrugadas, com pubescência esparsa. Proendosternito (Fig. 14) pouco desenvolvido, de aspecto triangular, fusionado na linha média e inclinado para o bordo anterior do prosterno, as projeções laterais alongadas, subparalelas à margem anterior da cavidade cotilóide. Mesendosternito (Figs 18, 19) pouco esclerotinizado, anguloso, obliquamente dirigido para o mesepimero e não fusionado a este; parte distal mais longa que a basal. Mesoscuto (Fig. 23) sem apódema interno; placa estridulatória bem desenvolvida, ovalada. Metendosternito (Figs 18, 20-22); braços curtos, perpendiculares às lâminas; estas cilíndricas mais longas que o pedúnculo, separadas por chanfro raso; tendões anteriores bem distanciados entre si. Metasterno, exceto no disco, superficialmente microcorrugado com pubescência esbranquiçada aparente.

Élitros com pontos grossos, profundos e densos, a escultura mais fina e superficial no terço apical; pubescência amarelada, esparsa. Cada élitro com duas carenas irregulares, uma dorsal, da base até o terço apical, e outra próximo à sutura, pouco manifesta. Extremidades truncadas, um pouco oblíquas para a sutura.

Asa (Fig. 17). Célula da Radial desenvolvida, de aspecto transverso; Setor Anterior (SA) sinuosa; Setor (S) presente; s-m alongada, sinuosa; Média Anterior ausente; Média (M) um pouco alongada; Plical (P) não angulosa na base, com vestígios da Empusal (E); Ea unida na base à Plical; transversa $2 \mathrm{Aa}$ evanescente. Árculo bem definido. Sem área carenada na base da Radial. Lobo anal algo reduzido.

Fêmures com pontuação fina, densa, com aspecto um pouco áspero, e cerdas castanhas, densas. Fêmures posteriores ultrapassam o ápice elitral por aproximadamente um terço de seu comprimento. Empódio (Fig. 24) com a porção distal muito reduzida, sem cerdas.

Urosternitos fina, rasa e densamente pontuado-corrugados; pubescência esbranquiçada densa, moderadamente longa, bem aparente sobre o tegumento escuro.

Terminália. Oitavo segmento (Figs 34, 35) quase tão longo quanto largo, os lados pouco convergentes para o ápice este ligeiramente bissinuado; apófise esternal curta. Arco ventral (Fig. 36) em forma de forquilha, o dorsal reduzido a uma membrana. Tégmen (Figs 37, 38): peça anelar convergente, aguçada na região apical; lobos laterais bem desenvolvidos, pigmentados, cilíndricos. Lobo médio (Figs 39, 40): lobo dorsal conspicuamente mais curto que o ventral, arredondadoanguloso no ápice; o ventral com ápice arredondado; apófises basais curtas; saco interno curto, a região posterior microespiculada; na região mediana com duas peças esclerotinizadas, pequenas, triangulares. 

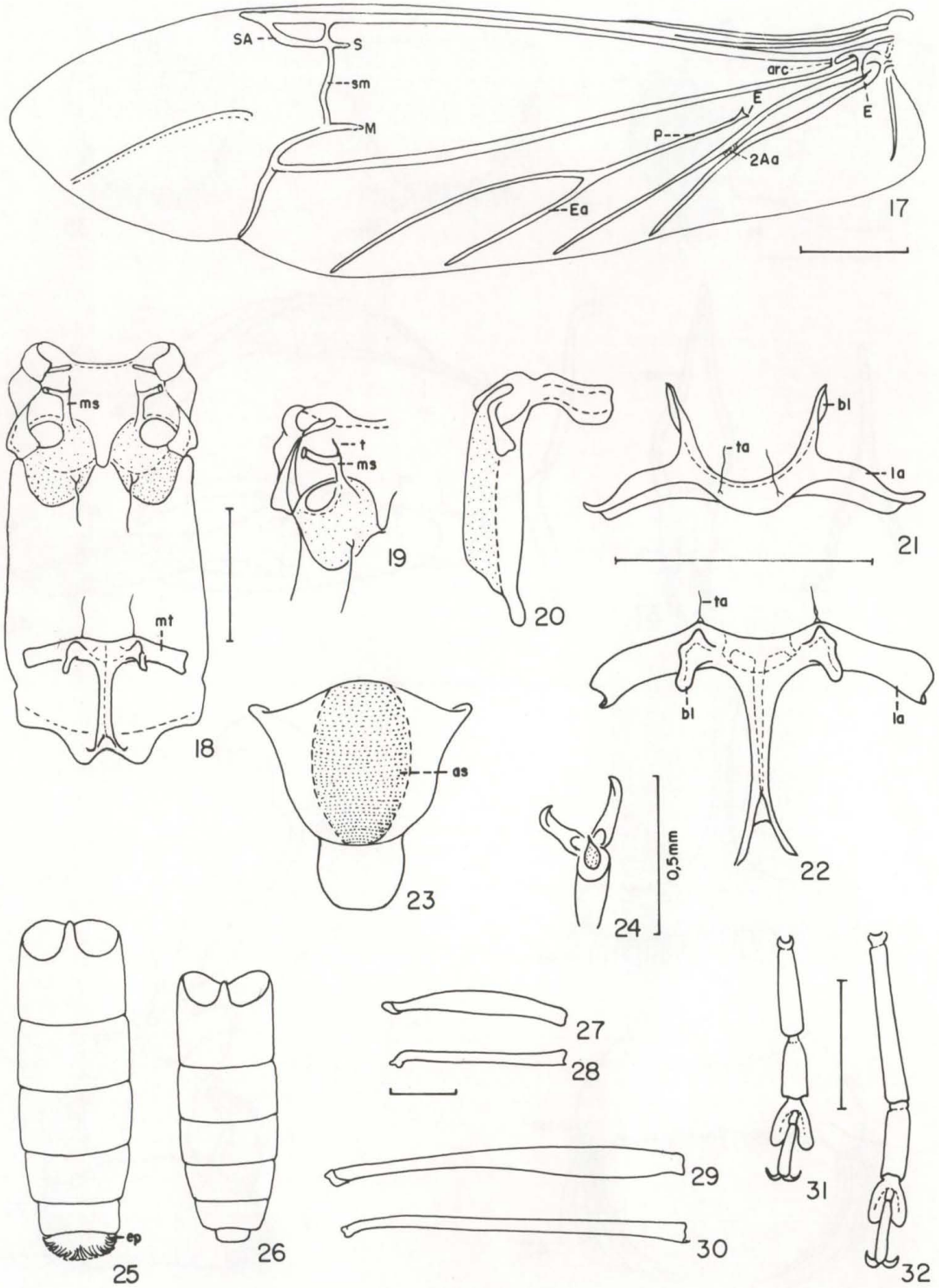

Figs 17-32. Chariergus tabidus. (17) Asa; (18) meso- e metasterno, vista dorsal interna; (19) mesendosternito; (20-22) metendosternito, lateral, anterior e dorsal; (23) mesoscuto e escutelo; (24) empódio; (25) abdômen, fêmea; (26) abdômen, macho; (27) fêmur anterior; (28) tíbia anterior; (29) metafêmur; (30) metatíbia; (31) tarso anterior; (32) metatarso. (arc) Árculo; (as) placa estridulatória; (bl) braços laterais; (E) empusal; (Ea) ramo a da empusal; (ep) escova de pêlos do sétimo urotergito; (la) lâminas; (M) média; ( $\mathrm{ms}$ ) mesendosternito; ( $\mathrm{mt}$ ) metendosternito; (P) plical; (SA) Setor Anterior; (S) Setor; (sm) transversa setor-média; (ta) tendões anteriores; $(\mathrm{t})$ tendão; (2Aa) ramo a da segunda Anal. Figs 20-23, 25-30, respectivamente, na mesma escala. Barra $=1 \mathrm{~mm}$, exceto Fig. 24 . 

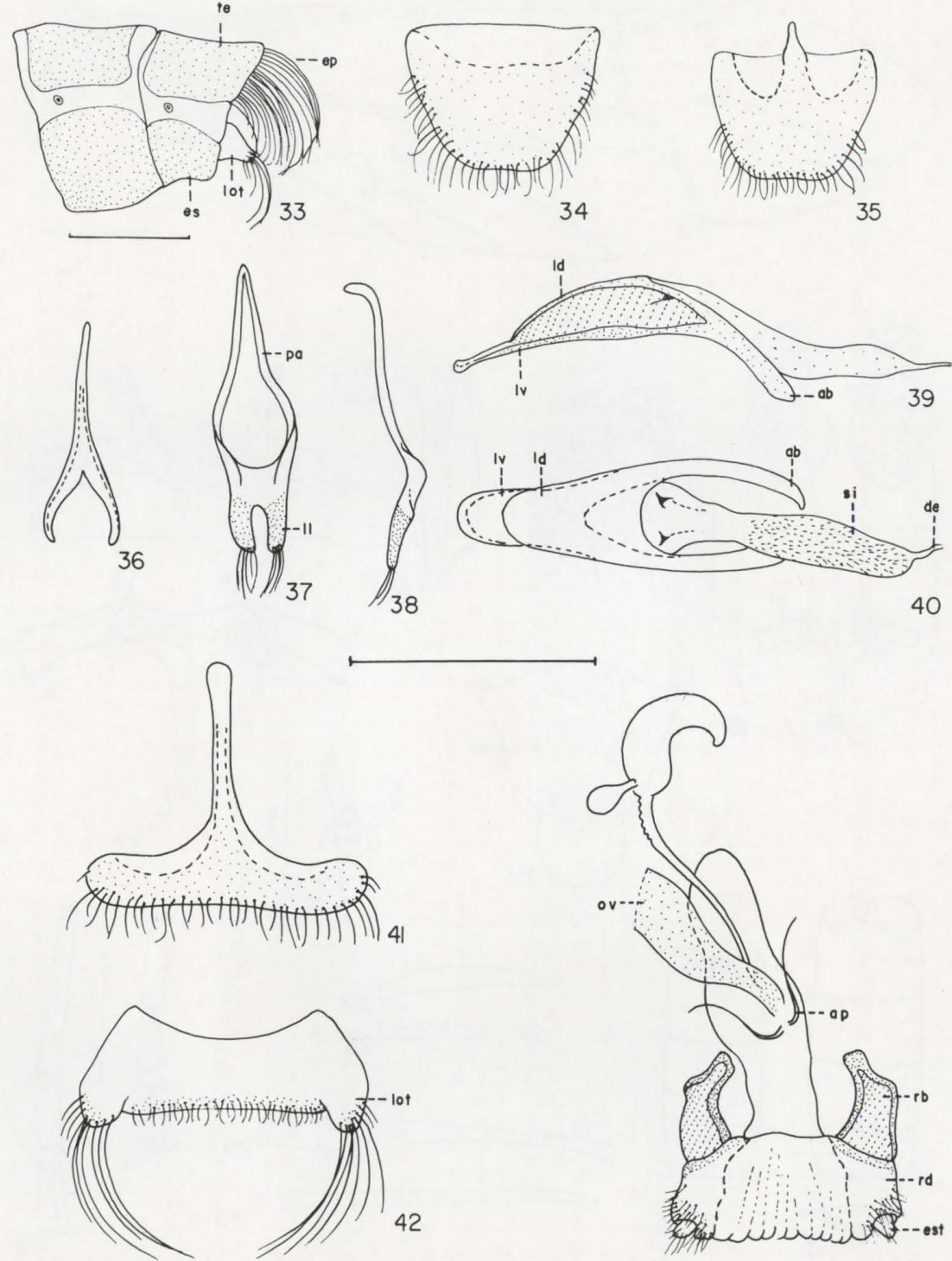

Figs 33-43. Chariergus tabidus. (33, 41-43) Fêmea: (33) últimos segmentos do abdômen, lateral; (41) oitavo esternito; (42) oitavo tergito; (43) ovipositor. (34-40) Macho: (34) oitavo tergito; (35) oitavo esternito; $(36)$ arco ventral; $(37,38)$ tégmen, dorsal, lateral; $(39,40)$ lobo médio, lateral, dorsal. (ab) Apódemas basais, (ap) apódemas, (de) duto ejaculatório, (ep) escova de pêlos do sétimo urotergito, (es) sétimo urosternito, (est) estilos, (Id) lobo dorsal, (II) lobos laterais, (lot) lobo lateral do oitavo tergito, (Iv) lobo ventral, (ov) oviduto comum, (pa) peça anelar, (rb) região basal do ovipositor, (rd) região distal do ovipositor, (si) saco interno, (te) sétimo urotergito. Barra $=1 \mathrm{~mm}$. 
Fêmea. Semelhante ao macho. Antenas ultrapassam o ápice elitral em 2,5 artículos. Fêmures posteriores pouco mais longos que o corpo. Lados do protórax fina e densamente pontuados e pubescentes. Terminália. Oitavo segmento fortemente transverso; esternito (Fig. 41) com apófise longa; o tergito (Fig. 42) com lobos laterais providos de longas cerdas, espessadas e curvas. Ovipositor (Fig. 43) curto; região basal tão longa quanto a distal, dividida, com os bordos fortemente esclerotinizados. Estilos curtos e apicais. Apódemas na base do oviduto comum longos e delgados. Espermateca bem desenvolvida; glândula da espermateca arredondada, de inserção basal.

Dimensões, em mm, macho/fêmea, respectivamente. Comprimento total, 10,2-8,2/10,8-9,2; comprimento do protórax, 2,2-1,7/2,2-1,8; largura do protórax, 1,7-1,2/1,7-1,5; comprimento do élitro, 7,2-6,0/7,8-6,7; largura umeral, 1,8-1,4/1,81,6 .

Material-tipo. Não examinado. KLUG (1825: 461) não faz referência ao número de exemplares e não fornece maiores detalhes sobre a procedência.

Discussão. Vide comentários em C. caeruleus.

Material examinado. BRASIL, Goiás: $1 \mathrm{~F}$ (MZSP); Goiatuba, $1 \mathrm{~F}$ (MNRJ), Jataí, 1 M, 1 F (MNRJ); Leopoldo Bulhões, 1 M (MZSP); Vianópolis, 2 F (MZSP). Espírito Santo: 2 M, 1 F (MZSP); Santa Tereza, 1 F (DZUP). Minas Gerais: Passa Quatro (Fazenda Campos, 1500m), 1 F (MZSP); Santa Bárbara (Serra do Caraça, 800m), 2 M, 4 F (MZSP); Virgínia (Fazenda Campos, 1500m), 1 F (MZSP). Rio de Janeiro: Rio de Janeiro, 2 M, 1 F (MZSP), (Corcovado) 6M, 3 F (MNRJ), 1M, 1 F (MZSP), 17 M, 13 F (DZUP); Itatiaia (Parque Nacional do Itatiaia, 700m), $1 \mathrm{~F}$ (MNRJ). São Paulo: Barueri, 2 F (MZSP), Monte Alegre (Fazenda Santa Maria, $1100 \mathrm{~m}$ ), 1 F (MZSP); São José do Barreiro (Serra da Bocaina, 1650m), 1 M, 6 F (MNRJ); São Bernardo, 1 F (MZSP); São Paulo, 2 M, 2 F (MZSP). Paraná: Antonina, 1 M, 1 F (DZUP); Curitiba, 2 F (MZSP); Morretes, 1 M, 2 F (DZUP); Piraquara, 1 M (DZUP); Ponta Grossa, 2 M, 5 F (DZUP); Rio Negro, 1 F (MZSP); Telêmaco Borba, 1 F (DZUP). Santa Catarina: Mafra, 4 M, 1 F (MNRJ), 1 F (MZSP); São Bento do Sul, 2 F (DZUP). Rio Grande do Sul: Porto Alegre, 1 M (MZSP).

\section{Chariergus caeruleus Napp \& Reynaud, 1998}

Fig. 98

Chariergus caeruleus Napp \& Reynaud, 1998: 155, 157, fig. 1.

Muito semelhante a C. tabidus, difere:

Élitros azul-metálicos, freqüentemente com estreita faixa basal alaranjada. Antenas e pernas negras a castanho-avermelhadas. Metasterno, metacoxas e urosternitos negros a castanhos.

Protórax inerme aos lados. Élitros bastante alongados e estreitos; em toda a superfície, com pontos profundos, subcontíguos a corrugados; pubescência castanho-avermelhada; extremidades obliquamente truncadas a ligeiramente emarginadas. Fêmures com pontuação fina, rasa, mais adensada nos mesofêmures; cerdas castanhas, decumbentes, adensadas. Metafêmures, nos machos, ultrapassam o ápice elitral por quase metade de seu comprimento. Metasterno com pubescência esparsa. 
Urosternitos fina, rasa e densamente pontuado-corrugados; pubescência esbranquiçada, curta, pouco aparente.

Dimensões, em mm, macho/fêmea, respectivamente. Comprimento total, 9,0-6,8/10,0-6,2; comprimento do protórax, 1,8-1,3/2,0-1,3; largura do protórax, 1,4-1,1/1,5-1,0; comprimento do élitro, 6,5-5,0/7,3-4,5; largura umeral, 1,5-1,2/1,71,2 .

Material-tipo. Holótipo macho de Pedra Azul, Minas Gerais, Brasil (MNRJ) e 81 parátipos (MNRJ, DZUP, MZSP), examinados.

Material examinado. BRASIL, Bahia: Encruzilhada(Motel da Divisa, Estrada Rio-Bahia, km 960, 960m), 1 F, XI.1972, Seabra \& Roppa leg. (MNRJ, parátipo). Minas Gerais: Águas Vermelhas, 1 M, XI.1970, F.M. Oliveira leg. (MNRJ, parátipo); Pedra Azul, 1 M, XI.1972, Seabra \& Oliveira leg. (MNRJ, holótipo), 5 M, 1 F, XII.1970, F.M. Oliveira leg., 1 M, XII.1970, 4 M, 3 F, X.1972, 20 M, 16 F, XI.1972, Seabra \& Oliveira leg. (MNRJ, parátipos), 10 M, 8 F, XI.1972, Seabra \& Oliveira leg. (DZUP, parátipos), 3 M, 3 F, XI.1972, Seabra \& Oliveira leg. (MZSP, parátipos). Espírito Santo: Colatina, 1 M, III.1972, F.M. Oliveira leg. (MNRJ, parátipo); Linhares, 1 M, 4.XII.1971, A.C. Domingos leg. (DZUP, parátipo).

\section{Allopeba gen.n.}

Etimologia. Do grego, alloios $=$ diferente e do tupi, $p e b a=$ perna.

Espécie-tipo: Chariergus paranaensis Napp \& Reynaud, 1998, por designação presente.

Cabeça pouco projetada à frente dos olhos (Fig. 46). Distância entre a inserção das mandíbulas e o alvéolo antenal cerca de um terço maior que o diâmetro do alvéolo. Fronte (Fig. 47) plana, transversa, inclinada a subvertical, levemente deprimida entre os tubérculos anteníferos. Estes não projetados, arredondados. Área malar, no maior comprimento com cerca de dois terços do diâmetro do lobo ocular inferior; no menor comprimento, pouco mais longa que a metade. Olhos (Figs 46, 47) chanfrados, finamente granulados, moderadamente desenvolvidos; lobos inferiores moderadamente projetados, cerca de três vezes mais largos que os superiores; ligação entre os lobos oculares aproximadamente igual à metade da largura de um lobo superior; lobos superiores estreitos, tão afastados entre sí quanto 4,5 vezes a largura de um lobo. Submento (Fig. 45) com projeção curta e transversa entre a inserção das maxilas. Mandíbulas (Figs 49, 50) delgadas, de seção triangular, não angulosas no terço apical, o ápice aguçado. Artículo apical dos palpos maxilares e labiais (Figs 51,53) moderadamente alongados, robustos, estreitados na base, um pouco dilatados para os ápices, estes truncados.

Antenas com onze artículos, filiformes, desarmadas, sem sulcos ou carenas, mais longas que o corpo nos dois sexos; nos machos ultrapassam o ápice elitral em três artículos. Escapo cilíndrico, pouco e gradualmente alargado para o ápice, sem sulcos ou depressões, pouco mais longo que metade do comprimento do III (Fig. 54). Este cerca de um quarto mais longo que o IV; V pouco mais longo que IV; VIII tão longo quanto o III; XI cerca de um quarto mais curto que o III, não ou levemente apendiculado. 
Protórax (Figs 55-57) mais longo que largo, nitidamente constrito na região anterior e projetado a cada lado à frente da constrição. Lados sinuosamente alargados para o meio com dois tubérculos: um após a constrição anterior, pouco pronunciado, e outro mediano, mais projetado. Pronoto com duas calosidades látero-basais pouco manifestas. Prosterno, nos machos, sem pontuação sexual. Processo prosternal (Fig. 58) triangular na região anterior, depois estreitado entre as coxas anteriores. Cavidades cotilóides anteriores angulosas aos lados, largamente abertas atrás. Processo mesosternal (Fig. 61) triangular, o ápice alcança aproximadamente a metade da coxa média. Cavidades cotilóides médias abertas aos lados. Metasterno quase tão longo quanto o pró- e mesosterno somados. Metepisterno sinuosamente estreitado para trás.

Élitros (Figs 100,101) cerca de 3,5 vezes tão longos quanto o protórax, na base nitidamente mais largos que este; úmeros arredondados; lados subparalelos até quase $o$ ápice. Extremidades arredondadas em conjunto.

Pernas com comprimentos crescentes, as posteriores cerca de $1,5 \times$ mais longas que as anteriores. Fêmures (Figs 68,70) algo robustos, gradualmente clavados, sem sulcos ou carenas, as abas apicais arredondadas; metafêmures ultrapassam o ápice elitral pelo ápice do fêmur. Tíbias (Figs 69,71) cilíndricas, delgadas, não carenadas. Esporões tibiais curtos e subiguais. Tarsos (Figs 72-74) moderadamente alongados; metatarsômero I cerca de um terço mais longo que o protarsômero I e pouco mais curto que os metatarsômeros II-III somados. Escovas tarsais sem faixa glabra.

Abdômen (Fig. 75) com urosternito VI parcialmente visível; urosternito V transverso, quase tão largo quanto o IV, truncado-emarginado no ápice.

Fêmea. Semelhante ao macho. Antenas ultrapassam o ápice elitral em dois artículos; artículo XI cerca de um terço mais curto que o III, subigual ao X. Fêmures pouco robustos, os posteriores não alcançam o ápice elitral. Abdômen (Fig. 76) com cinco esternitos visíveis; urosternito $\mathrm{V}$ emarginado no ápice; sétimo tergito com escova pigidial de pêlos longos, avermelhados, curvados para baixo e para frente.

Discussão. Allopeba é semelhante a Rierguscha, diferenciando-se por: 1) conformação da cabeça (Figs 46, 47): alvéolos antenais afastados da inserção da mandíbula; genas arredondadas, paralelas em vista frontal; fronte mais alongada, inclinada; 2) peças bucais (Figs 49-53): mandíbulas arredondadas no terço apical; artículos apicais dos palpos robustos, estreitados na base e um pouco dilatados para os ápices; 3 ) pernas (Figs 68-74, 101): fêmures gradualmente clavados; metatarsos alongados, tão longos quanto metade do comprimento da metatíbia, metatarsômero I mais longo que os dois seguintes somados e não intumescido; 4) processos intercoxais (Figs 58, 61): prosternal não laminar entre as procoxas, alcança a margem posterior destas; o mesosternal triangular; 5) escapo cilíndrico, com dois terços do comprimento do antenômero III (Fig. 54). Em Rierguscha (Figs 84-97, 99) os alvéolos antenais são próximos da inserção das mandíbulas, a fronte é curta e vertical e as genas são aguçadas e divergentes; as mandíbulas são angulosas no terço apical e os artículos apicais dos palpos são cilíndricos; os fêmures são abruptamente clavados, os metatarsos são curtos com cerca de um terço do comprimento da metatíbia, o metatarsômero I intumescido e mais curto que os dois 
seguintes somados; o processo prosternal é laminar e reduzido e o mesosternal é mais largo, com ápice rombo. A venação alar de Rierguscha bicolor difere da de Allopeba signaticornis pela célula da Radial desenvolvida e transversa, s-m curva na base, Média um pouco alongada, base da Plical não dirigida para a Cubital e com vestígios da Empusal (aspecto de forquilha) e Ea, na base, unida à Plical. Nestes aspectos é mais semelhante à venação alar de Chariergus tabidus.

\section{Allopeba signaticornis (Lucas, 1857) comb.n.}

Figs $44-55,58-83$

Chariergus (Oregostoma) signaticornis Lucas, 1857: 188, pl. 12, figs 3, 3a-b.

Chariergus signaticornis; Gounelle, 1911: 252. -Monné, 1993: 28 (cat.). - Monné \& Giesbert, 1994: 103. - Napp \& Reynaud, 1998: 157.

Macho. Cabeça, protórax, escutelo e élitros alaranjados, concolores, ou os élitros pouco mais claros. Antenas, pernas, mesosterno, metasterno e urosternitos, processo prosternal e margens anteriores das cavidades coxais anteriores desde negros até avermelhados; artículos antenais IX-X branco-amarelados.

Cabeça (Figs 44-47), na fronte e vértice, fina e densamente pontuada com densa pubescência avermelhada; genas e face ventral lisas, subglabras; elevada na região do vértice e moderadamente constrita após os lobos oculares. Suturas gulares (Fig. 45) curtas e convergentes. Mandíbulas (Figs 48-50) pouco projetadas no ápice; bordo cortante com um dente mediano; franja de pêlos ao longo do bordo interno, presente. Maxilas (Fig. 53): cardo desenvolvido; estipe transverso, dividido em basie dististipe. Gálea cilíndrico-capitada, alcança a base do terceiro artículo do palpo; região apical com pêlos não capitados; com anel esclerotinizado na base, esta retraída entre o palpífero e a lacínea. Palpo maxilar cerca de um terço mais longo que o labial; artículo apical tão longo quanto os dois anteriores somados; robusto, estreitado na base, depois um pouco dilatado para o ápice, este truncado; segundo artículo pouco mais longo que o terceiro. Lábio (Figs 51, 52): mento trapezoidal. Lígula membranosa, na face externa com área central pigmentada com longos pêlos laterais; bordo apical com chanfro acentuado, estreito e arredondado-anguloso;lobos laterais bem desenvolvidos, alcançam a base do artículo apical do palpo; face interna com duas estreitas faixas laterais de pêlos. Artículo apical do palpo labial robusto, pouco alongado, estreitado na base, pouco dilatado para o ápice, este truncado; palpíferos individualizados.

Escapo com pontos finos, rasos e esparsos, e pubescência castanho-avermelhada esparsa. Artículos antenais III-XI fina e densamente pontuados, a pubescência gradualmente adensada para os distais; face ventral dos III-VI com cerdas alongadas, mais densas no III; IX-X com densa pubescência branco-amarelada.

Protórax (Fig. 55) gradualmente expandido após a constrição anterior, esta moderadamente marcada. Pronoto muito fina e densamente pontuado, com densa pubescência avermelhada. Lados do protórax com pontos finos, rasos, esparsos, a pubescência esparsa. Prosterno quase liso, fina e superficialmente estriado, com pubescência esbranquiçada muito curta e esparsa; processo prosternal com pubes- 

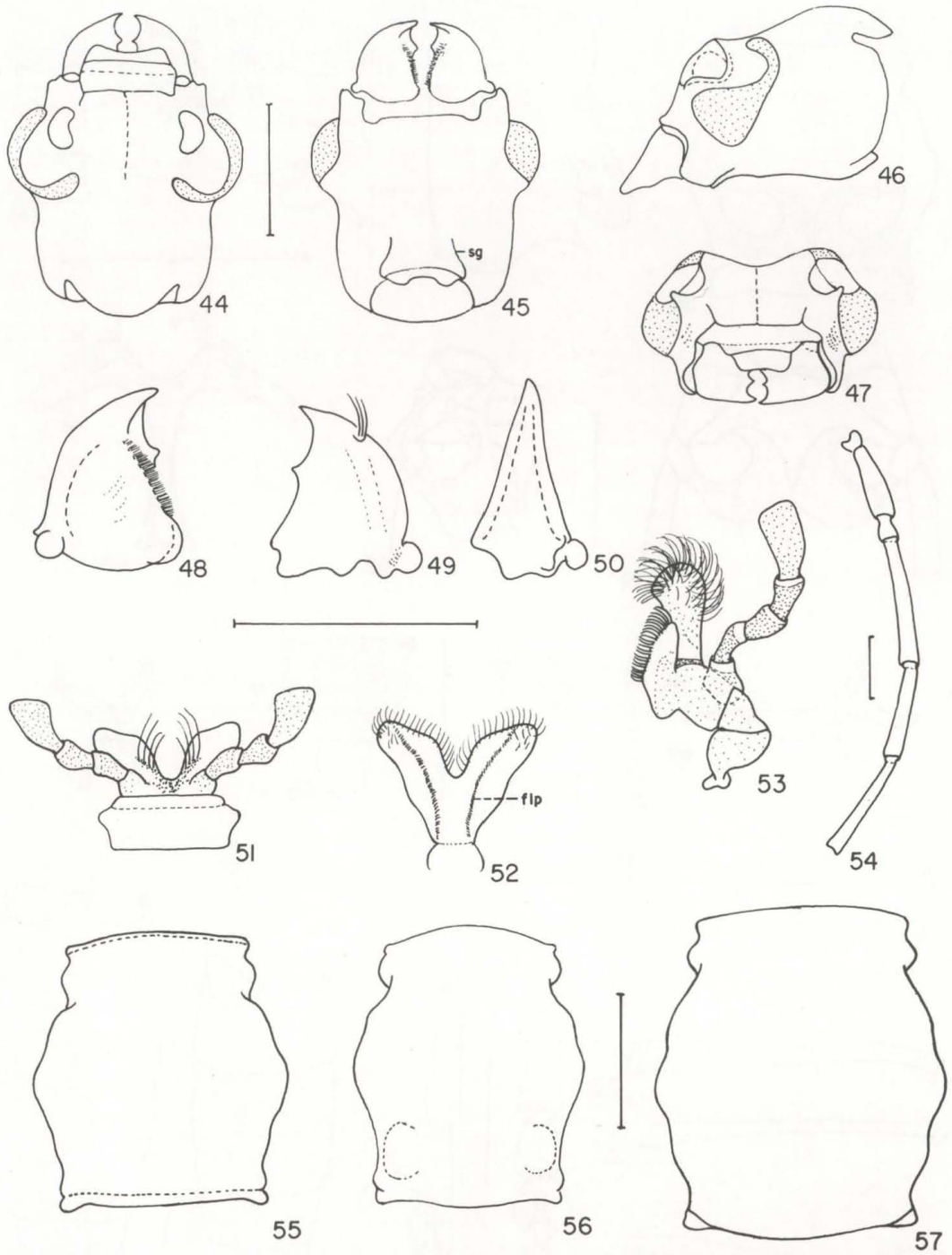

Figs 44-57. Allopeba signaticornis. (44-47) Cabeça, vistas dorsal, ventral, lateral e anterior; (48-50) mandíbula, vistas ventral, dorsal e lateral; $(51,52)$ lábio, vistas dorsal e ventral; $(53)$ maxila; (54) antena; (55) protórax, dorsal; (56) A. paranaensis, protórax dorsal; (57) $A$. quadripunctata, idem. (flp) Franja lateral de pêlos. Figs 44-47, 48-53, respectivamente, na mesma escala. Barra $=1 \mathrm{~mm}$.

cência branco-sedosa densa. Proendosternito (Fig. 60) de aspecto triangular, fusionado na linha média, obliquamente dirigido para o bordo anterior do prosterno, com duas projeções laterais desenvolvidas, subparalelas às projeções medianas. Mesendosternito (Fig. 62) pouco esclerotinizado, anguloso, não fusionado à parede interna 

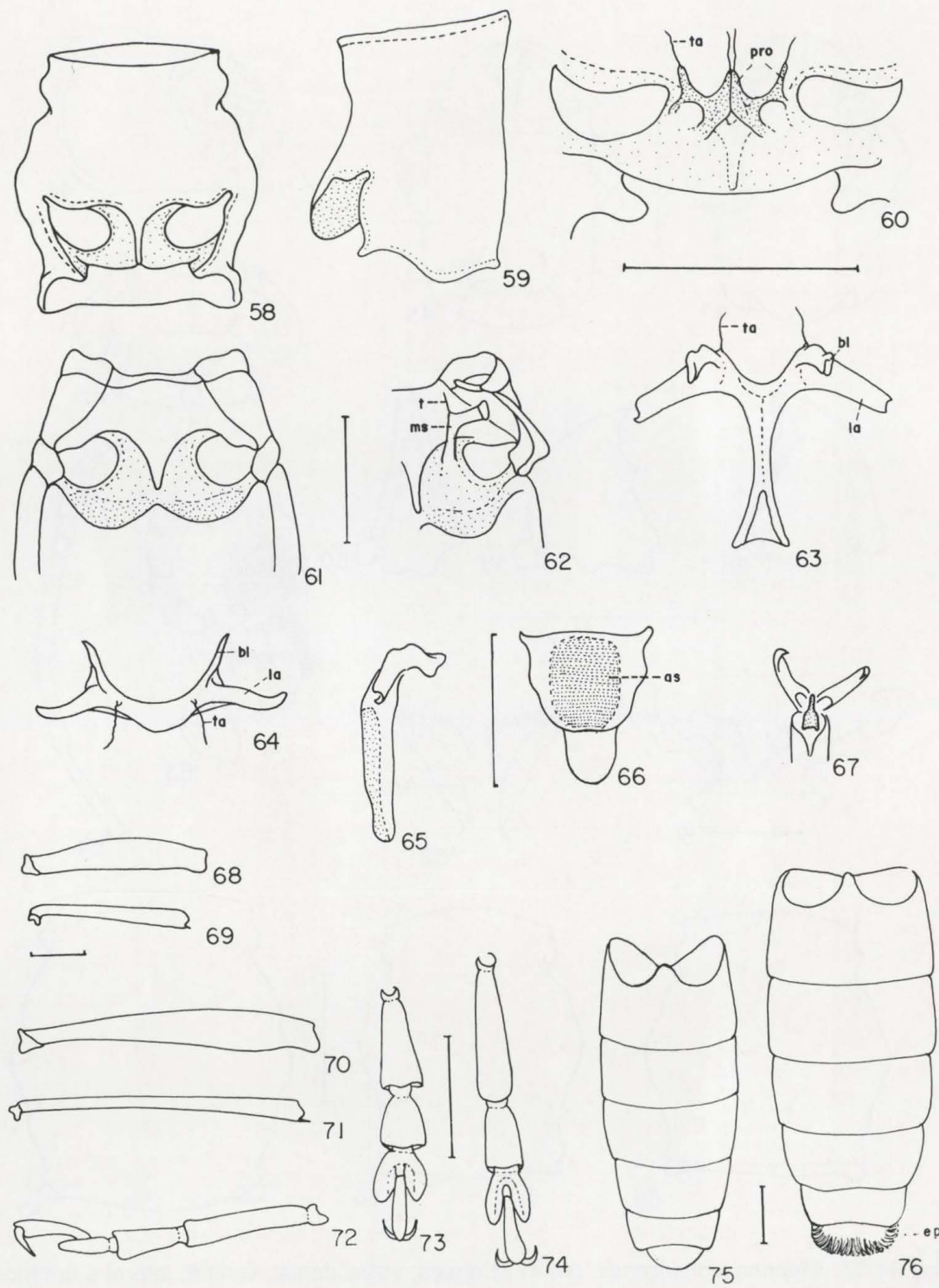

Figs 58-76. Allopeba signaticornis. (58-59) Protórax, ventral e lateral; (60) proendosternito; (61) mesosterno; (62) mesendosternito; (63-65) metendosternito, vistas dorsal, anterior e lateral; (66) mesoscuto e escutelo; (67) empódio; (68) fêmur anterior; (69) tíbia anterior; (70) metafêmur; (71) metatíbia; (72) metatarso, lateral; (73) tarso anterior; (74) metatarso, dorsal; (75) abdômen, macho; (76) abdômen, fêmea. (as) Placa estridulatória, (bl) braços laterais, (ep) escova de pêlos do sétimo urotergito, (la) lâminas, (ms) mesendosternito, (pro) proendosternito, (t) tendão, (ta) tendões anteriores. Figs 58-61, 63-67, 68-71, 72-74, respectivamente, na mesma escala. Barra $=1 \mathrm{~mm}$. 
do mesepimero; região distal pouco mais longa que a basal. Mesoscuto (Fig. 66) sem apódema interno; área estridulatória desenvolvida, subarredondada. Metendosternito (Figs 63-65) com braços curtos, perpendiculares às lâminas; estas cilíndricas, pouco alongadas, separadas por chanfro estreito, subarredondado, moderadamente acentuado; pedúnculo alongado; tendões anteriores distanciados entre si. Mesosterno, metasterno e urosternitos com densa pubescência branco-sedosa, moderadamente longa e decumbente.

Élitros fina, densa e uniformemente pontuados, opacos; pubescência avermelhada, densa; cerdas eretas ausentes. Escutelo finamente pontuado com pilosidade vermelho-alaranjada. Asa (Fig. 77): célula da radial pequena, subtriangular; Setor Anterior (SA) sinuosa; Setor (S) ausente; s-m retilínea, alongada; Média Anterior (MA) presente; Média (M) reduzida; Plical (P), na base, sem vestígios da Empusal, levemente inclinada em direção à Cubital; Ea separada da Plical e unida à $1 \mathrm{~A}(1 \mathrm{~A}$ + Ea); transversa 2Aa desenvolvida, um pouco oblíqua. Lobo anal desenvolvido. Árculo bem definido. Sem área carenada na base da Radial.

Fêmures com pontuação fina e esparsa; pubescência e pilosidade acastanhadas, esparsas. Empódio (Fig. 67) sem cerdas, a região distal moderadamente desenvolvida.

Terminália. Oitavo segmento transverso; tergito (Fig. 79) com lados subparalelos no terço basal, com ápice amplamente arredondado; esternito (Fig. 78), na base com lados subparalelos, depois convergentes para o ápice, este truncado-arredondados; apófise esternal curta. Arco ventral (Fig. 80) em forma de forquilha; o dorsal presente, reduzido. Tégmen (Figs 80, 81): peça anelar convergente, pouco aguçada no ápice; região distal dividida em lobos laterais apenas no ápice. Lobo médio (Figs 82, 83): lobo dorsal distintamente mais curto que o ventral, ligeiramente acuminado no ápice; o ventral com ápice bissinuado; apófises basais curtas; saco interno curto, com a região posterior densamente microespiculada e duas peças esclerotinizadas, pequenas, triangulares, na região mediana.

Fêmea. Semelhante ao macho. Terminália como em Chariergus tabidus.

Dimensões, em mm, macho/fêmea, respectivamente. Comprimento total, 11,8-8,5/12,7-8,3; comprimento do protórax, 2,3-1,7/2,5-1,6; largura do protórax, $1,8-1,3 / 2,2-1,3$; comprimento do élitro, 8,3-6,2/9,3-5,3; largura umeral, 2,3$1,8 / 2,7-1,8$.

Material-tipo. Não examinado. LuCAS (1857: 188) indica "Minas Geraes" como procedência.

Discussão. Semelhante a A. quadripunctata: 1) pela conformação do protórax, com a constrição anterior pouco marcada e não fortemente expandido após a mesma; 2) cabeça, pronoto e élitros opacos, muito fina e densamente pontuados e pubescentes. Distingue-se desta espécie pelos élitros unicolores, sem faixas ou manchas negras e pelo escutelo alaranjado, concolor com os élitros.

Material examinado. Brasil, Minas Gerais: Passa Quatro (Fazenda Campos), 2 M, 10 F (MZSP). Rio de Janeiro: Itatiaia, 1 M, 1 F (MNRJ); Teresópolis, 5 F (MNRJ), (Parque Nacional da Serra dos Órgãos), 1 M, 3 F (MZSP), 1 F (MNRJ). 
São Paulo: Campos do Jordão (1600m), 1 M, 2 F (MNRJ), 1 F (MZSP); São José do Barreiro (Serra da Bocaina, 1650m), 10 M, 11 F (MNRJ), 4 M (DZUP). Paraná: Colombo, 1 M (DZUP); Curitiba, 1 F (MNRJ); Guarapuava, 7 M, 4 F (DZUP); Piraquara, 1 F (DZUP); Ponta Grossa, 2 F (DZUP); Telêmaco Borba, 14 M, 8 F (DZUP). Santa Catarina: Corupá, 1 F (MNRJ); Mafra, 1 F (DZUP), 3 M, 1 F (MNRJ), 2 M, 2 F (MZSP); Pinhal, 1 F (MNRJ); Rio Negrinho, 3 F (DZUP); São Bento do Sul (Rio Vermelho), 1 F (MNRJ), 1 F (DZUP); Serra Geral (28'02 49'35, $1700 \mathrm{~m}), 1 \mathrm{~F}$ (MZSP).
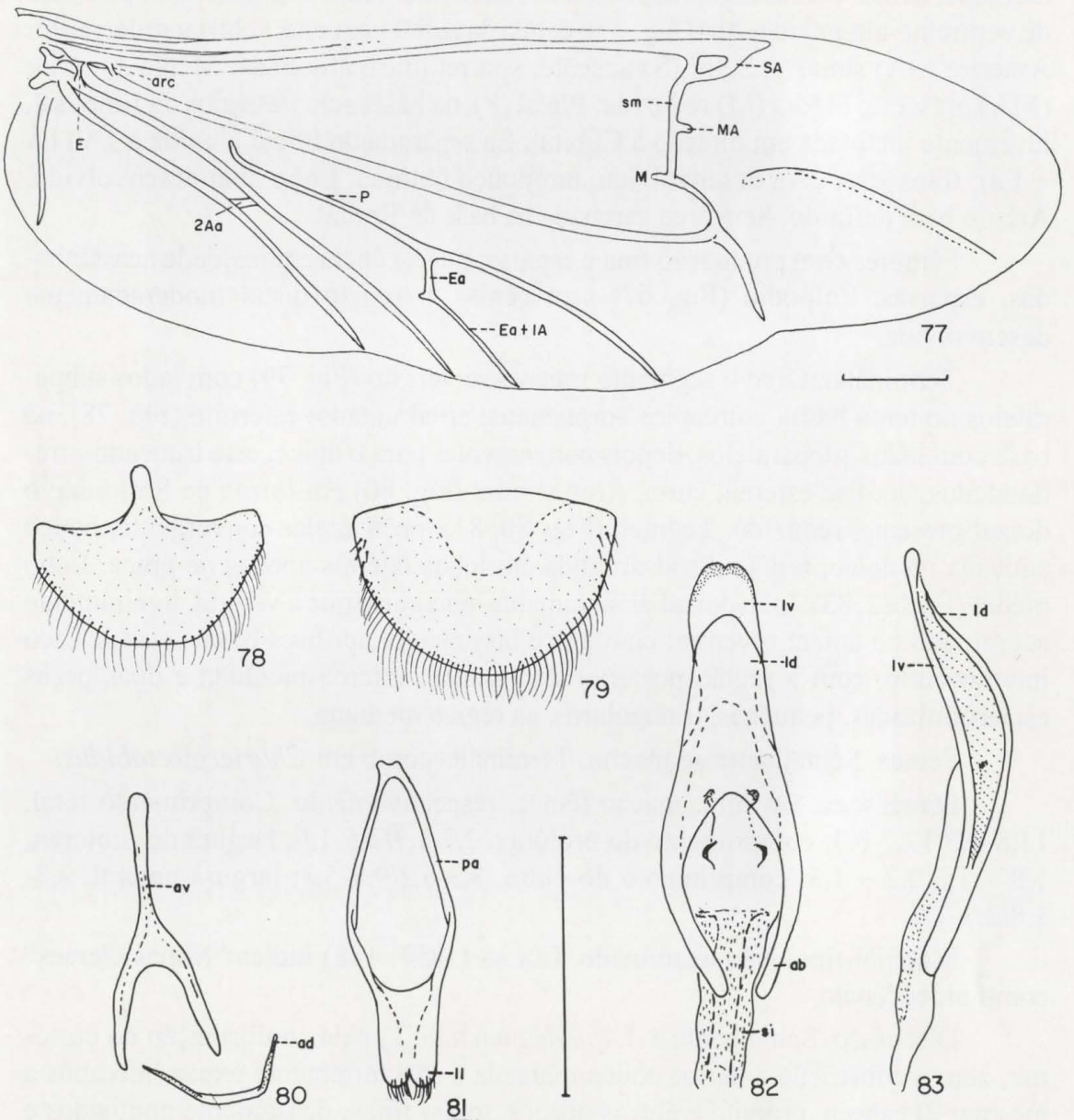

Figs 77-83. Allopeba signaticornis. (77) Asa; (78) oitavo esternito, macho; (79) oitavo tergito, macho; (80) arcos dorsal e ventral; (81) tégmen; (82-83) lobo médio. (ab) Apófises basais, (ad) arco dorsal, (av) arco ventral, (arc) árculo, (E) Empusal, (Ea) ramo a da Empusal, (Id) lobo dorsal, (II) lobos laterais, (Iv) lobo ventral, (M) Média; (MA) Média Anterior, (P) Plical, (pa) peça anelar, (SA) Setor Anterior, (si) saco interno, (sm) transversa radial-média, (1A) primeira Anal, (2Aa) ramo a da segunda Anal. Barra $=1 \mathrm{~mm}$. 


\section{Allopeba quadripunctata (Lucas, 1857) comb.n.}

Figs 57,100

Chariergus quadripunctatus Lucas, 1857: 188, pl. 12, Figs 4, 4a. - Monné, 1993: 28 (cat.). - Monné \& Giesbert, 1994: 103. - Napp \& Reynaud, 1998: 157.

Muito semelhante a A. signaticornis, difere:

Protórax (Fig. 57) menos dilatado após a constrição anterior, o tubérculo antemediano pouco individualizado. Élitros amarelo-alaranjados, mais claros que o protórax; cada élitro com duas faixas negras, transversais, estreitas, da sutura até a margem externa, uma antemediana e outra no início do terço posterior dos élitros. Escutelo negro com pilosidade castanha. Mesosterno, metasterno e urosternitos com pubescência esbranquiçada esparsa, pouco aparente no centro do metasterno e pouco mais adensada nos urosternitos.

Dimensões, em mm, macho/fêmea, respectivamente. Comprimento total, 12,7-10,2/13,0-11,3; comprimento do protórax, 2,5-2,0/2,4-2,2; largura do protórax, 2,2-1,7/2,0-1,8; comprimento do élitro, 9,0-7,5/9,3-8,3; largura umeral, 2,5$2,1 / 2,8-2,3$.

Material-tipo. Não examinado. Aparentemente, LUCAS (1857: 188) examinou apenas um macho proveniente de Minas Gerais. Na figura apresentada por LUCAS (1857, pr. 12, fig. 4) e pela descrição original, cada élitro apresenta duas manchas transverso-ovaladas que não alcançam a sutura e a margem externa, como ocorre em A. paranaensis. Entretanto, a figura mostra distintamente que o pronoto tem pilosidade. Foram examinados diapositivos de um exemplar da Coleção Thomson (MNHN) e um com etiqueta de Dejean (BMNH, Fig. 100) com manchas elitrais semelhantes e identificados como Chariergus quadripunctatus Lucas. Nestes exemplares, o pronoto e os élitros são opacos, muito fina e densamente pontuados e pubescentes como em A. signaticornis.

Discussão. Vide comentários em A. paranaensis.

Material examinado. BRASIL, 1 M, 5.IX.1923 (MZSP). Paraná: São José dos Pinhais, 2 M, 1 F (DZUP). Santa Catarina: São Bento do Sul (Rio Natal), 2 F, (Rio Vermelho, $800 \mathrm{~m}$ ), $2 \mathrm{~F}$ (MNRJ).

\section{Allopeba paranaensis (Napp \& Reynaud, 1998) comb.n. Figs 56, 101}

Chariergus paranaensis Napp \& Reynaud, 1998: 156, 157, fig. 2.

Muito semelhante a $A$. quadripunctata, difere:

Cabeça e pronoto quase lisos, subglabros, brilhantes. Protórax (Fig. 56) fortemente constrito à frente, abruptamente dilatado após a constrição anterior, depois pouco mais alargado para o meio. Élitros com pontuação fina e pubescência esparsas, superfície brilhante; áreas negras ou castanhas formam faixas com margens irregulares, as anteriores até em forma de máculas arredondadas. Escutelo densamente revestido por pubescência branco-sedosa contrastante com o tegumento escuro. Urosternitos com pubescência branco-sedosa, moderadamente longa, moderadamente densa. Fêmures com pontuação fina e esparsa, com pubescência esbranquiçada, sedosa, esparsa. 
Dimensões, em mm, macho/fêmea, respectivamente. Comprimento total, 11,5-10,8/11,7-10,7; comprimento do protórax, 2,2-2,0/2,2-2,0; largura do protórax, 2,0-1,7/1,8-1,7; comprimento do élitro, 8,2-7,7/8,5-,8; largura humeral, 2,5$2,2 / 2,3-2,2$.
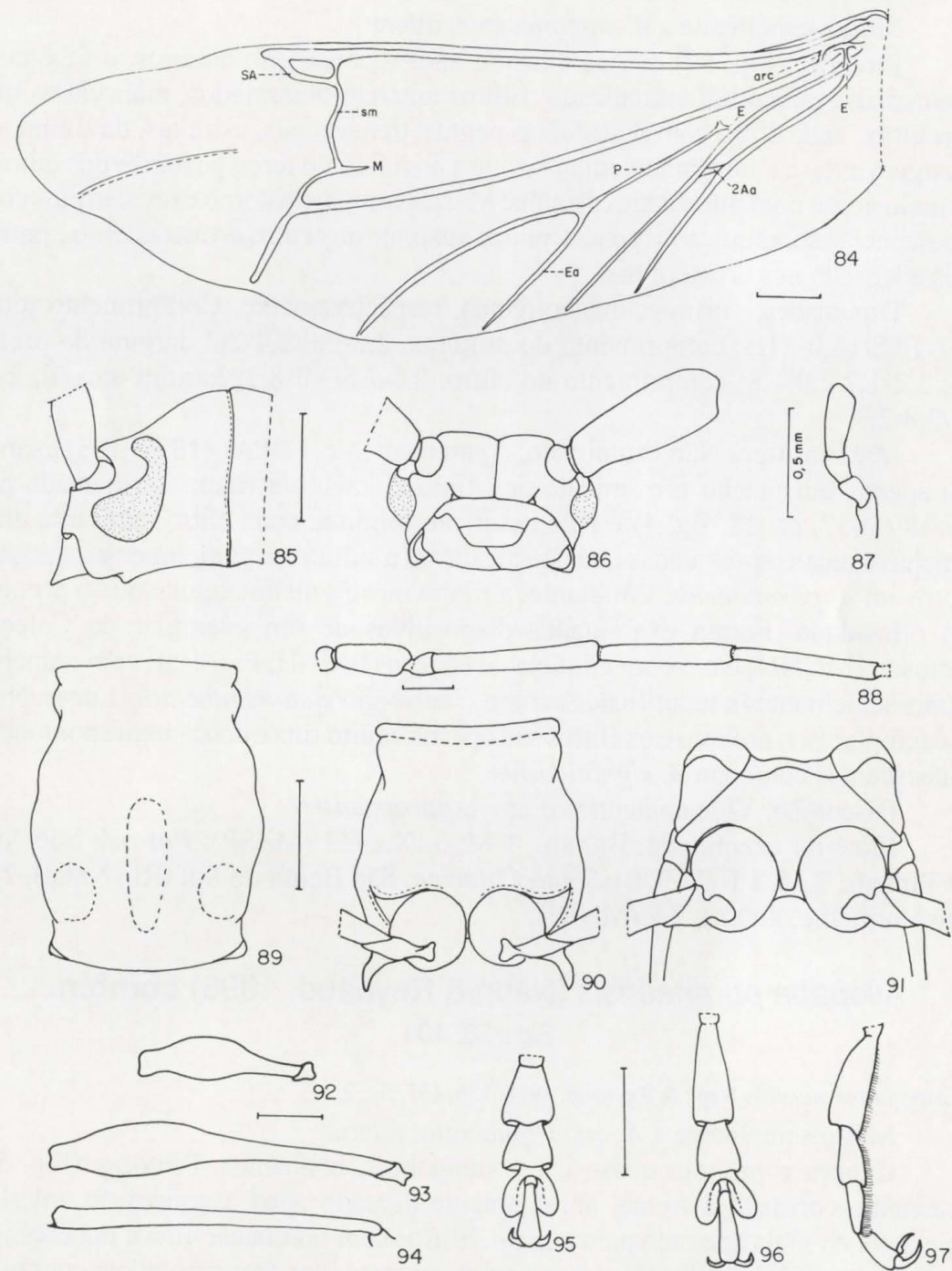

Figs 84-97. Rierguscha bicolor. (84) Asa; (85-86) cabeça, lateral, anterior; (87) palpo maxilar; (88) antena; (89-90) protórax, dorsal, ventral; (91) mesosterno; (92) fêmur anterior; (93) metafêmur; (94) metatíbia; (95) tarso anterior; (96-97) metatarso, dorsal, lateral. (arc) Árculo, (E) Empusal, (Ea) ramo a da Empusal, (M) Média, (P) Plical, (SA) Setor Anterior, (sm) transversa radial-média, $(2 \mathrm{Aa})$ ramo a da segunda Anal. Barra $=1 \mathrm{~mm}$, exceto Fig. 87. 
Material examinado. Brasil, Paraná: Quatro Barras (Pico do Paraná, 1700m), 1 M (Holótipo), 1 F (Parátipo), 22.I.1970, Laroca \& Becker leg. (DZUP). Santa Catarina: Serra Geral (28’02 49’35, 1700m), 1 F (DZUP, parátipo). Rio Grande do Sul: Porto Alegre, 1 M, 1926, P. Buck leg. (MZSP, parátipo).

\section{Rierguscha Viana, 1970}

Rierguscha Viana, 1970: 145. - Monné, 1993: 29 (cat.). - Monné \& Giesbert, 1994: 105.

Espécie-tipo: Rierguscha bicolor Viana, 1970, por designação original.

Cabeça (Figs 85,86 ) saliente, pouco projetada à frente dos olhos, a região posterior aos lobos oculares superiores elevada; distância entre o alvéolo antenal e a inserção da mandíbula menor que o diâmetro do alvéolo. Fronte curta, fortemente transversa, convexa, não deprimida entre os tubérculos anteníferos. Estes não projetados, arredondados. Área malar, no maior comprimento subigual a dois terços do diâmetro do lobo ocular inferior; na menor comprimento, subigual a um terço. Genas um pouco aguçadas, em vista frontal, divergentes. Submento com projeção curta e transversa entre a inserção das maxilas. Olhos finamente granulados, chanfrados; lobos inferiores moderadamente desenvolvidos; ligação entre os lobos pouco mais estreita que o lobo superior; lobos superiores com um terço da largura dos inferiores, tão distantes entre si quanto quatro vezes a largura de um lobo. Mandíbulas um pouco robustas, angulosas no terço apical, aguçadas no ápice. Artículos apicais dos palpos maxilares e labiais cilíndricos, truncados no ápice, tão a mais longos que os dois anteriores somados.

Antenas com onze artículos, filiformes, desarmadas, sem sulcos ou carenas, ultrapassam o ápice elitral em quatro artículos. Escapo robusto, sem sulcos ou depressões, tão longo quanto metade do comprimento do III (Fig. 88). Este cerca de um quarto mais longo que o IV; V pouco mais longo que IV; VI-IX com comprimentos subiguais; XI aproximadamente um terço mais curto que o III.

Protórax (Fig. 89) subcilíndrico, mais longo que largo, moderadamente constrito na região anterior e projetado a cada lado à frente da constrição. Lados pouco e gradualmente alargados para o meio, subtuberculados após a constrição anterior e ao nível do meio. Pronoto um pouco irregular, com duas gibosidades látero-basais pouco manifestas. Prosterno, nos machos, sem pontuação sexual. Processo prosternal (Fig. 90) triangular, curto, quase laminar entre as coxas anteriores, o ápice alcança a metade de uma procoxa. Coxas anteriores subcontíguas, salientes, um pouco cônicas. Cavidades cotilóides anteriores fortemente angulosas aos lados, largamente abertas atrás. Processo mesosternal (Fig. 91) triangular, truncado no ápice. Mesocoxas globosas, salientes. Cavidades cotilóides médias abertas aos lados. Metasterno tão longo quanto o pró- e mesosterno somados. Metepisterno sinuosamente estreitado para trás.

Élitros cerca de quatro vezes tão longos quanto o protórax, na base mais largos que este; úmeros arredondados; lados paralelos até quase os ápices, estes conjuntamente arredondados.

Pernas com comprimentos crescentes, as posteriores quase duas vezes tão longas quanto as anteriores. Fêmures (Figs 92, 94, 99) abruptamente clavados, a clava ocupa metade do comprimento do fêmur; pedúnculos cilíndricos, sem sulcos 




Figs 98-101. (98) Chariergus caeruleus Napp \& Reynaud, parátipo macho de Colatina, Espírito Santo, III.1972, F.M. Oliviera, comprimento, 9,0 mm; (99) Rierguscha bicolor Viana, macho de Camarapa, Santa Cruz, Bolívia, comprimento, $14,0 \mathrm{~mm}$; (100) Allopeba quadripunctata (Lucas), macho (BMNH), reproduzido do diapositivo; (101) Allopeba paranaensis (Napp \& Reynaud) holótipo macho, comprimento, $10,8 \mathrm{~mm}$. 
ou carenas; abas apicais arredondadas; metafêmures ultrapassam pouco o ápice elitral. Tíbias (Fig. 94) cilíndrico-deprimidas, não carenadas. Esporões tibiais curtos. Tarsos (Figs 95-97) curtos, os posteriores pouco mais longos que os anteriores; metatarsômero I algo intumescido, tão longo quanto os II-III somados. Escovas tarsais compactas, sem faixa glabra.

Abdômen com urosternito VI parcialmente visível; urosternito V transverso, truncado-emarginado no ápice.

Fêmea. Semelhante ao macho, segundo VIANA (1970): antenas ultrapassam ápice elitral por três artículos; urosternito $\mathrm{V}$ truncado no ápice; sétimo urotergito com densa escova de pêlos avermelhados, longos, curvados para baixo e para frente.

\section{Rierguscha bicolor Viana, 1970}

Figs 84-97, 99

Rierguscha bicolor Viana, 1970: 145, fig. 1. - Monné, 1993: 29 (cat.). - Monné \& Giesbert, 1994: 105.

Macho. Cabeça vermelha, protórax vermelho a acastanhado. Antenas negras, o escapo vermelho, os artículos IX-XI branco-amarelados. Pernas negras com as clavas dos fêmures vermelhas. Élitros verde-metálicos, brilhantes. Escutelo vermelho. Mesosterno, metasterno e urosternitos castanhos a castanho-avermelhados.

Cabeça (Figs 85, 86) com pontuação fina e rasa, esparsa na fronte, a pubescência pouco aparente. Genas e face ventral quase lisas, subglabras. Fronte abaulada. Artículo apical dos palpos maxilares (Fig. 87) e labiais mais longo que os dois anteriores somados. Escapo com pontos irregulares, mais densos na base, e cerdas castanhas bem aparentes. Artículos antenais III-V finamente pontuados com cerdas acastanhadas muito adensadas, mais evidentemente no III e quase formam escova na face ventral dos III-IV; VI-XI finamente pubescentes; IX-XI com pubescência branco-amarelada. Pronoto fina e densamente pontuado, exceto sobre área centro longitudinal, na metade basal, ligeiramente elevada; pubescência amarelada, conspícua. Lados do protórax com pontuação mais rasa e esparsa que a do pronoto, a pubescência pouco aparente. Prosterno quase liso, subglabro, finamente estriado; processo prosternal liso, glabro. Mesosterno, Metasterno e urosternitos com pontuação fina, rasa e esparsa; pubescência e pilosidade esbranquiçadas, esparsas. Élitros microesculturados, subopacos, com pontuação fina, pouco aparente, regularmente distribuída; pubescência amarelo-esbranquiçada moderadamente densa, contrastante com o tegumento verde-metálico; cerdas ausentes. Escutelo revestido por pilosidade branco-amarelada. Asa (Fig. 84): célula da Radial desenvolvida, aspecto transverso; Setor Anterior (SA) sinuosa; Setor (S) ausente; s-m alongada, sinuosa, curva na base; Média Anterior (MA) ausente; Média (M) um pouco alongada; Plical (P) não angulosa na base, com vestígios da Empusal (E); Ea unida na base à Plical; transversa $2 \mathrm{Aa}$ desenvolvida, um pouco oblíqua; árculo bem definido; sem área carenada na base da Radial; lobo anal desenvolvido. Fêmures com pontuação fina, rasa e muito esparsa e cerdas castanhas pouco aparentes.

Dimensões, mm, macho. Comprimento total, 13,7-12,7; comprimento do protórax, 2,5-2,3; largura do protórax, 2,00-1,8; comprimento do élitro, 9,5-9,3; largura umeral, 2,5-2,4. 
Material-tipo. Espécie descrita com base em dois exemplares provenientes de "Salta (Depto. Chicoana, Maray), Argentina" (Viana 1970: 152). Holótipo macho depositado no MACN; alótipo, no IMLT. Examinamos diapositivo do holótipo.

Material examinado. BolíviA, Santa Cruz: Camarapa/ El funal, $1 \mathrm{M}$ (MCNZ); Caballero (Laguna Verde), 2 M (MZSP).

\section{Rierguscha viridipennis (Bruch, 1925).}

Chenoderus viridipennis Bruch, 1925: 209, fig. 11.

Rierguscha viridipennis; Viana, 1970: 152, fig. 2. - Monné, 1993: 29 (cat.). - Monné \& Giesbert, 1994: 105.

Macho. Castanho a castanho-avermelhado-escuro. Élitros verde-metálicos, escuros, opacos.

Cabeça com pontuação rasa, fina, densa a corrugada; pubescência pouco aparente; fronte e genas microesculturadas a pontuação e pubescência muito esparsas. Artículo apical dos palpos maxilares e labiais subigual aos dois anteriores somados. Fronte ligeiramente convexa, na linha média mais curta que o clípeo. Escapo com pontos grossos algo corrugados, mais densos para a base, e cerdas castanhas bem aparentes. Artículos III-V(VI) com cerdas castanhas densas, mais evidentes no III e na face ventral dos IV-V, a pubescência inaparente; VII-XI fina e densamente pubescentes. Pronoto e lados do protórax muito fina e densamente pontuado-corrugados, revestidos por densa pubescência esbranquiçada, sedosa, contrastante com o tegumento escuro. Prosterno como em $R$. bicolor. Regiões laterais do mesosterno, metasterno e urosternitos rasa e finamente corrugados, com pubescência e pilosidade esbranquiçadas moderadamente densas; cerdas esbranquiçadas, longas, no disco do metasterno e dos urosternitos. Élitros densamente microcorrugados, opacos, revestidos por pubescência esbranquiçada, sedosa, quase oblitera o tegumento; cerdas ausentes. Escutelo revestido por pubescência esbranquiçada, sedosa. Fêmures com pontos finos, superficiais, esparsos, e cerdas avermelhdas, decumbentes, moderadamente densas.

Fêmea. Antenas ultrapassam o ápice elitral em 1,5-2,0 artículos. Cabeça microesculturada, a pontuação quase inconspícua; genas lisas. Artículo antenal III o mais longo; V-VI com comprimentos subiguais, pouco mais longos que IV; X-XI curtos, com aproximadamente metade do comprimento do III. Fêmures posteriores não atingem o ápice elitral.

Dimensões, em mm, respectivamente macho/fêmea. Comprimento total, 9,0/10,8; comprimento do protórax, 1,9/2,0; largura do protórax, 1,5/1,7; comprimento do élitro, 6,6/7,9; largura umeral, 1,8/2,3.

Material-tipo. De acordo com VIANA (1970: 152): holótipo macho, alótipo e três parátipos machos provenientes de Andalgalá, Catamarca, Pedro Joergensen leg., depositados no MACN. Examinamos um macho (MNRJ), com as seguintes etiquetas: 1) Rca. Argentina, Prov. Catamarca, 190, C. Bruch; 2) Cotypus; 3) Chenoderus viridipennis Bruch; 4) Chenoderus viridipennis $\mathrm{m}$. C. Bruch Determ.

Material examinado. ARgentina, Catamarca: $1 \mathrm{M}$ (MNRJ, Cotypus). Tucumán: $1 \mathrm{~F}, \mathrm{R}$. Golbach (MNRJ, ex. col. Bosq). 
AGRADECIMENTO. Ao Prof. Dr. Albino M. Sakakibara (DZUP) pelas fotografias.

\section{REFERÊNCIAS BIBLIOGRÁFICAS}

AURIVILliUS, C. 1912. Coleopterorum Catalogus, pars 39, Cerambycidae: Cerambycinae. Berlin, W. Junk, 574p.

BATES, H.W. 1867. New genera of longicorn Coleoptera from the River Amazons. Entomologist's mon. Mag. 4: 22-28.

BLACKWELDER, R.E. 1946. Cheklist of the coleopterous insects of Mexico, Central America, the West Indies and South America. Part 4. Bull. U.S. Nat. Mus. 185: 551-763.

BRUCH, C. 1925. Coleópteros nuevos y poco conocidos. Physis 8: 199-211.

DeJEAN, P.F. 1837. Catalogue des Coleóptères de la collection de M. le Comte

Dejean, troisième édition, revue corrigée et aumengtée. Paris, Méquignon-Marvis Pére et Fils, XIV+503p.

GounELLE, E. 1911. Liste des cérambycides de la région de Jatahy, Etat de Goyaz, Brésil. Annls Soc. ent. France 80: 103-252.

KLUG, J.C. 1825. Entomologie Brasilianae specimen sistens insectorum coleopterorum nondum descriptorum centuriam. Nova Acta Acad. Caesar. Leop. Carol. 12 (2): 421-476.

LACORDAire, J. T. 1869. Histoire Naturelle des Insectes. Genera des Coléoptères..., Paris, Libr. Encycl. de Roret, 9 (1): 1-409.

LUCAS, P.H. 1857. Entomologie. In: Animaux nouveaux ou rares recueillis pendant l'expédition dans les parties centrales de l'Amérique du Sud, de Rio de Janeiro a Lima, et de Lima au Para, exécutée par ordre du Gouvernement Français pendant les années 1843 a 1847, sous la direction du Comte F. de Castelnau. Paris, Bertrand, 204p.

MARQUES, M.I. \& D.S. NAPP. 1996. Revisão e transferência para Rhopalophorini (Coleoptera, Cerambycidae, Cerambycinae) dos gêneros Coremia A.-Serville, 1834 e Merocoremia Marques, 1994. Revta bras. Ent. 40 (3/4): 379-423.

MonNÉ, M.A. 1993. Catalogue of the Cerambycidae (Coleoptera) of the Western Hemisphere. Part VIII. São Paulo, Sociedade Brasileira de Entomologia, 97p.

MonNÉ, M.A. \& E.F. GIESBERT. 1994. Cheklist of the Cerambycidae and Disteniidae (Coleoptera) of the Western Hemisphere. Burbank, Wolfsgarden Books, XIV+409p.

NAPP, D.S. 1994. Phylogenetic relationships among the subfamilies of Cerambycidae (Coleoptera, Chrysomeloidea). Revta bras. Ent. 38 (2): 265-419.

NAPP, D.S. \& D.T. REYNAUD. 1998. New species of Chariergus White and Ethemon Thomson (Coleoptera, Cerambycidae, Compsocerini). Insecta Mundi 12 (1-2): 155-159.

Thomson, J. 1860. Essai d'une classification de la famille des cérambycides et matériaux pour servir a une monographie de cette famille. Paris, $404 \mathrm{p}$.

1864. Systema cerambycidarum ou exposé de tous les genres compris dans la famille des cerambycidaes et familles limitrophes. Mém. Soc. r. Sci. Liège 19: 1-540. 
ViANA, M.J. 1970. Um nuevo género y espécie de Cerambycidae de la República Argentina (Coleoptera, Cerambycinae, Compsocerini). Revta Mus. argent. Cienc. nat. Bernardino Rivadavia (Zool.) 10 (10): 145-153.

WHITE, A. 1855. Catalogue of the coleopterous insects in the collection of British Museum. Longicornia 2. London, 8, p.175-412.

Recebido em 16.VI.1998; aceito em 15.VI.1999. 